\title{
A Review of Accelerated Response Actions Available to the Environmental Restoration Program: Selected Case Histories and Associated Issues
}
J. D. Smyth
R. D. Quinn
S. J. Gianti

May 1991

Prepared for the U.S. Department of Energy under Contract DE-AC06-76RLO 1830

Pacific Northwest Laboratory Operated for the U.S. Department of Energy by Battelle Memorial Institute 


\title{
DISCLAIMER
}

This report was prepared as an account of work sponsored by an agency of the United States Government. Neither the United States Government nor any agency thereof, nor Battelle Memorial Institute, nor any of their employees, makes any warranty, expressed or implied, or assumes any legal liability or responsibility for the accuracy, completeness, or usefulness of any information, apparatus, product, or process disclosed, or represents that its use would not infringe privately owned rights. Reference herein to any specific commercial product, process, or service by trade name, trademark, manufacturer, or otherwise does not necessarily constitute or imply its endorsement, recommendation, or favoring by the United States Government or any agency thereof, or Battelle Memorial Institute. The views and opinions of authors expressed herein do not necessarily state or reflect those of the United States Government or any agency thereof.

\author{
PACIFIC NORTHWEST LABORATORY \\ operated by \\ BATTELLE MEMORIAL INSTITUTE \\ for the \\ UNITED STATES DEPARTMENT OF ENERGY \\ under Contract DE-ACO6-76RLO 1830
}

Printed in the United States of America

Available to DOE and DOE contractors from the

Office of Scientific and Technical Information, P.O. Box 62, Oak Ridge, TN 37831;

prices available from (615) 576-8401. FTS 626-840t.

Available to the public from the National Technical Information Service, U.S. Department of Commerce, 5285 Port Royal Rd., Springfield, VA 22161. 
PNL -7715

UC-902

\title{
A REVIEW OF ACCELERATED RESPONSE ACTIONS AVAILABLE TO THE ENVIRONMENTAL RESTORATION PROGRAM: SELECTED CASE HISTORIES AND ASSOCIATED ISSUES
}
J. D. Smyth
R. D. Quinn
S. J. Gianti (a)

May 1991

\author{
Prepared for \\ the U.S. Department of Energy \\ under Contract DE-AC06-76RL0 1830
}

Pacific Northwest Laboratory

Richland, Washington 99352
(a) $\mathrm{CH} 2 \mathrm{M} \mathrm{HilT}$
Reston, Virginia 22090




\section{PREFACE}

The Office of Environmental Restoration and Waste Management (EM): is a relatively new organization within the Department of Energy (DOE) complex. DOE-EM has been established to consolidate and manage department-wide environmental restoration and waste operation activities, extending to the development of new and more effective technologies. The Office of Environmental Restoration (ER) has mission requirements that fall within the purview of the EM organization. DOE-ER's mission is to address those aspects of assessment and cleanup of facilities that are no longer a part of active operations, but that may be contaminated with various quantities of radioactive, hazardous, and/or mixed waste. The Planning and Support Division (EM-43) has responsibilities across the DOE-ER complex that include coordinating areas of regulatory compliance. As its support contractor, Pacific Northwest Laboratory $(P N L)^{(a)}$ is assisting EM-43 in meeting the goals of its mission.

DOE's environmental restoration process promises to be lengthy and expensive. EM-43 is therefore seeking to streamline this process to reduce time and cost; at the same time, it seeks to develop technically and legally defensible environmental remediation activities. PNL is assisting in the development and investigation of creative mechanisms to streamline the environmental restoration process by drawing on experience gained by the Environmental Protection Agency under the Superfund Program. This effort has been entitled the Streamlining Task.

The overall goal of the Streamlining Task is to identify better, faster, and less expensive methods of accomplishing the assessment and remediation of the waste sites that are the responsibility of DOE-ER. In addition to this report ("A Review of Accelerated Response Actions Available to the Environmental Restoration Program - Selected (ase Histories and Issues"), other activities currently being implemented as part of the Streamlining Task include:

(a) Pacific Northwest Laboratory is operated for the U.S. Department of Energy by Battelle Memorial Institute under Contract DE-AC06-76RLO 1830. 
1. Observational Approach Guidance--providing observational approach workshops and follow-on guidance to DOE field offices and associated contractors.

2. Data Quality Objectives and Streamlining Activities--examining the use of data quality objectives associated with streamlining the cleanup process.

3. Environmental Restoration Cost-Model Baseline--estimating a baseline cost for DOE'S ER program to provide a measure of how technology development can make the ER program better, faster, and cheaper.

4. Remedial Investigation/Feasibility Study (RI/FS) Process--investigating the contrasts between the integrated RI/FS approach now advocated by EPA and the modular RI, FS approach in DOE's negotiated cleanup agreements. 


\section{SUMMARY}

Accelerated actions were developed by the Environmental Protection Agency (EPA) within the regulatory framework for initiating early cleanup action or accelerating ongoing cleanup action to abate, mitigate, or reduce risk to human health or the environment at a contaminated waste site. The purposes of this report are to review the regulatory frameworks available to initiate accelerated actions at sites on the National Priorities List (NPL) and to provide case histories of sites where accelerated actions have been implemented. The findings of this report are applicable to non-NPL waste sites also. Accelerated actions are of interest to the Department of Energy (DOE) for two primary reasons: 1) they are methods available to demonstrate progress in environmental restoration at DOE waste sites, and 2) a subset of accelerated actions, termed interim remedial actions, may be required in place of final actions to avoid violating National Environmental Policy Act (NEPA) guidelines during the development of DOE Office of Environmental Restoration and Waste Management's (DOE-EM's) Programmatic Environmentat Impact Statement (PEIS).

Accelerated actions available at DOE's waste sites include removal actions performed under removal or remedial authority and interim remedial actions performed as operable units. It is important to distinguish between removal and remedial actions because, although DOE has been granted authority to use both in its cleanup, the compliance requirements are substantially different for each. DOE's intent to comply with and integrate NEPA requirements into its environmental restoration activities is a complicating issue in implementing accelerated actions. DOE recently issued a NEPA compliance statement asserting that many of the removal actions DOE might perform were categorically excluded from NEPA requirements if EPA's statutory 1 imits on removal actions ( $\$ 2$ million and 12 months of onsite action) were met. Waivers to exceed these statutory limits are available for DOE's categorical exciusions. If NEPA requirements can be met (or if NEPA is not applicable), it should be possible to implement accelerated actions at DOE sites. The implications of DOE-ER's PEIS on accelerated actions has not yet been determined. DOE has stated that this will be handled on a site-by-site basis. 
To provide the case histories, interviews with staff and reviews of comp1 iance documents were conducted for sites in EPA Regions III, IV, and VII. The case histories reviewed included both removal actions and interim remedial actions. Insights and opinions from the staff concluded that these actions were useful to demonstrate progress. Some staff thought that the accelerated actions resulted in reduced costs compared to the typical remedial process. In EPA Region III, the removal actions implemented to demolish buildings and remove debris were thought to have reduced costs by minimizing the amount of time spent in remedial design (RD) and by using in-place emergency response contractors (ERCs). In EPA Region IV, staff thought that removal actions were probably less costly and resulted in accelerated cleanup action implementation. However, without a side-by-side comparison of accelerated actions and typical remedial actions, neither possible time nor cost savings can be verified or quantified.

The experience with accelerated actions at DOE's Weldon Spring Remedial Action Project demonstrates that NEPA requirements can be successfully integrated with the Comprehensive Environmental Response, Compensation, and Liability Act of 1980 (CERCLA) remedial requirements. The staff at We1don Spring stressed that their success was based on their credibility with regulators and the public. This credibility is achieved by negotiating openly and effectively with EPA and the state regulators and by including the public in the planning process. 


\section{ACKNOWLEDGMENTS}

In addition to the sources listed in this document, many other people contributed their insights, including PNL staff members Roy Gephart and Martin Siege1, CH2M HILL staff member Joan Miller, DOE-EH staff Rich Dailey and Randy Kaltrieder, and DOE-EM-43 Division Manager Bill Wisenbaker.

In particular, the draft GAeG (graphical approach to environmental guidance) package on removal actions at DOE sites under development at PNL for DOE-EH was used as a resource for Section 2. 

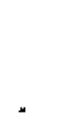


\section{GLOSSARY}

ARAR

CERCLA

COE

DOE

$\mathrm{EE} / \mathrm{CA}$

EIS

EM

EPA

ER

ERA

ERC

FFS

GAeG

IRA

NCP

NEPA

NPL

OSC

OSHA

OSWER

PEIS

PNL

PRP
Applicable or relevant and appropriate requirements

Comprehensive Environmentat Response, Compensation, and Liability Act

Corps of Engineers

Department of Energy

Engineering evaluation/cost analysis

Environmental Impact Statement

DOE Office of Environmental Restoration and Waste Management

Environmental Protection Agency

DOE Office of Environmental Restoration

Expedited response actions

Emergency response contractor

Focused feasibility study

Graphical approach to environmental guidance

Interim remedial action

National 0 il and Hazardous Substances Pollution Contingency Plan

National Environmental Policy Act

National priorities list

On-scene coordinator

Occupational Safety and Health Agency

Office of Solid Waste and Emergency Response

Programmatic Environmental Impact Statement

Pacific Northwest Laboratory

Potentially responsible party 


$\begin{array}{ll}\text { RA } & \text { Remedial action } \\ \text { RCRA } & \text { Resource Conservation and Recovery Act } \\ \text { RD } & \text { Remedial design } \\ \text { RI/FS } & \text { Remedial investigation/feasibility study } \\ \text { ROD } & \text { Record of decision } \\ \text { RPM } & \text { Remedial project manager } \\ \text { RR } & \text { Rapid response } \\ \text { WSSRAP } & \text { Weldon Spring Site Remedial Action Project }\end{array}$




\section{CONTENTS}

PREFACE $\ldots \ldots \ldots \ldots \ldots \ldots \ldots \ldots \ldots \ldots \ldots \ldots$

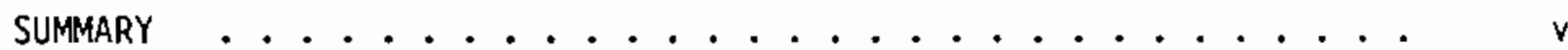

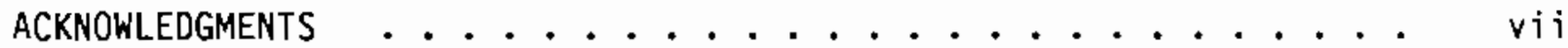

GLOSSARY ......................... ix

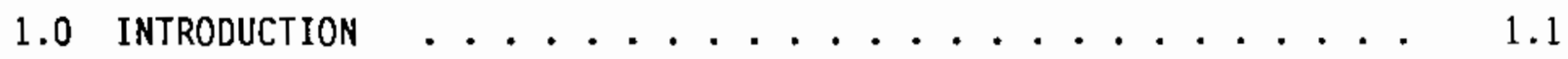

1.1 FOCUS AND APPROACH $\ldots \ldots \ldots \ldots . \ldots . \ldots . \ldots$

1.2 OVERVIEW AND LIMITS . . . . . . . . . . . . . 1.3

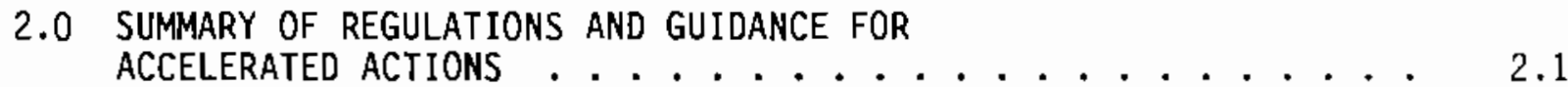

2.1 DEFINITION OF TERMS . . . . . . . . . . 2.1

2.1.1 Accelerated Response Actions ........ 2.2

2.2 REMOVAL ACTIONS . . . . . . . . . . . . 2.4

2.2.1 Applicability and Use ............ 2.5

2.2.2 Types of Removal Actions . . . . . . . . 2.6

2.3 INTERIM REMEDIAL ACTIONS $\ldots \ldots \ldots \ldots$

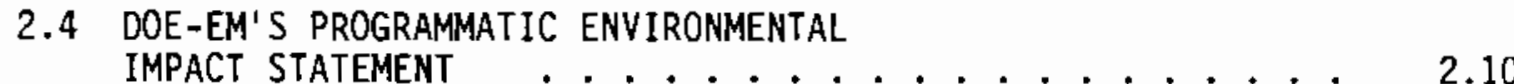

2.4.1 DOE's NEPA POlicy ................. 2.10

2.4.2 PEIS Outline .................... 2.11

3.0 ACCELERATED ACTION CASE HISTORIES AND

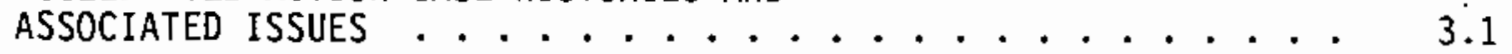

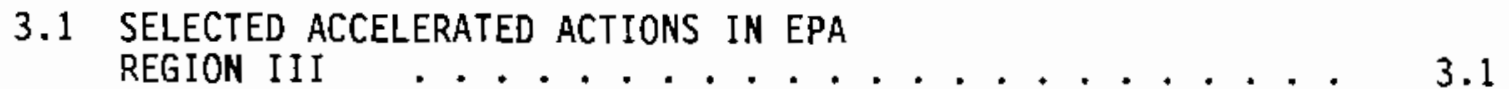

3.1 .1 Removal Actions ................ 3.2

3.1.2 Interim Remedial Actions at the
Greenwood Chemical Site ......... 3.4 
3.2 REgION IV PERSPECTIVE ON REMOVAL ACTIONS $\ldots \ldots \ldots . . . .3$ 3.2.1 Background . . . . . . . . . . . 3.5

3.2.2 Implementation Perspective . . . . . . 3.6

3.2 .3 Results . . . . . . . . . . . 3.6

3.3 ACCELERATED ACTIONS AT A DOE SITE IN

REGION VII $\ldots \ldots \ldots \ldots . \ldots . \ldots . \ldots . \ldots . \ldots$

3.3.1 Site Background . . . . . . . . . . 3.8

3.3.2 Removal Actions . . . . . . . . . . . 3.9

3.3.3 Interim Remedial Actions ......... 3.10

4.0 CONCLUSIONS . . . . . . . . . . . . . . 4.1

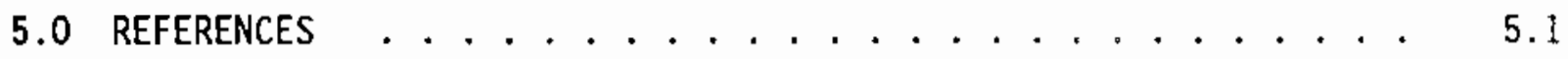

\section{FIGURE}

2.1 Accelerated Response Actions Under CERCLA . . . . . . . 2.3 


\subsection{INTRODUCTION}

DOE has stated its goal of completing environmental restoration activities within the next 28 years (DOE 1990). To achieve this commitment, DOE must conduct an efficient and effective waste-site remediation program. Accelerated actions may play an important role in achieving DOE's environmental restoration goals and commitments. Understanding the flexibility that is available within the regulatory framework to conduct accelerated activities and gathering knowledge of how these activities are implemented in the field are key elements to $\mathrm{DOE}^{\prime} \mathrm{s}$ effectiveness in this endeavor.

DOE-EM has also committed to preparing a Programmatic Environmental Impact Statement (PEIS) to fully assess the environmental consequences of its program, including DOE-ER's remedial activities (DOE 1990). The PEIS will also fulfill a DOE commitment to comply with the National Environmental Policy Act (NEPA). The impact of the PEIS on the schedule of restoration activities is unclear at this time; however, as stipulated by NEPA, until the PEIS becomes final (currently scheduled for 1993), any remedial actions conducted by DOE must be considered to be interim actions (i.e., not final actions) in order not to bias the outcome. This provides an added incentive for DOE to understand the regulations governing interim actions and the experiences that result from their implementation.

Motivated by these factors, DOE-ER has requested PNL to investigate the use of accelerated actions as a means to perform environmental remediation, consistent with the current regulatory framework under NEPA and the Comprehensive Environmental Response, Compensation, and Liability Act of 1980 (CERCLA). This report describes the response to that request. The purpose of the effort is twofold:

- to investigate and summarize the regulatory framework under which accelerated actions are permitted and are currently being performed

- to investigate, summarize, and evaluate case histories and issues of accelerated action implementation by EPA and DOE. 


\subsection{FOCUS AND APPROACH}

The focus of this task was to glean knowledge from EPA and DOE staff that have experience in implementing accelerated actions at waste sites. This effort consisted of three main components: 1) defining what accelerated actions are, 2) determining the uses and limitations of accelerated actions as defined by the appropriate regutations, and 3) exploring how accelerated actions are actually implemented in the field.

The approach to investigate these three components was first to gather and review regulations and guidance applicable to conducting accelerated actions. The sources used for this phase consisted of the National $0 i 1$ and Hazardous Substances Pollution Contingency Plan (NCP) (55 FR 8666) and various Environmental Protection Agency (EPA) Office of Solid Waste and Emergency Response (OSWER) Directives. An additional source of regulatory input was a draft-guidance package on removal actions at DOE sites that is being developed by PNL for DOE's Office of Environment, Safety, and Health.

Interviews with EPA and DOE staff from sites where accelerated actions have been or are being performed was the next phase of the investigation. EPA "Superfund" activities and compliance documentation in Regions III, IV, and VII, and DOE environmental restoration activities at the Weldon Spring Site Remedial Action Project (WSSRAP) were the primary sources of information.

An assumption was made at the outset of this effort that there is a discernible difference between the field interpretation and implementation of accelerated actions and the language and descriptions found in regulations and guidance. As a result, all three components of this report attempt to integrate the two different perspectives to provide a picture of how accelerated actions can be and actually are used. For example, definitions of the different types of accelerated actions were derived from language and definitions found in the NCP and OSWER Directives, combined with insight into "working" field terminology from the site visits. Hopefully, the integration of regulations and applications will add to the insights available from this report.

DOE is currently developing guidance on conducting accelerated actions. Terminology for $D O E^{\prime} s$ accelerated actions may be slightly different from that 
used by EPA, because many of the distinctions EPA makes between accelerated actions are based on funding issues that do not apply to DOE. This report explains and defines EPA accelerated action terminology and also identifies the major distinctions in accelerated actions that may be relevant to DOE's environmental restoration program.

\subsection{OVERVIEW AND LIMITS}

Following the introduction, this report is organized according to the main components of the investigation. The applicable regulations and guidance that define the uses and limitations of implementing accelerated actions are summarized in Section 2, as is the terminology used to describe accelerated actions by EPA and DOE. The third section contains a collection of case histories of accelerated actions performed, why they were implemented, and their current status or results. The conclusions drawn from having applied accelerated actions to DOE's environmental restoration activities and insights developed from the case histories are described in Section 4.

At $D O E$ sites and facilities, environmental restoration activities are being conducted under CERCLA for past practices and under the Resource Conservation and Recovery Act of 1984 (RCRA) for ongoing operations. This report focuses on accelerated actions performed under CERCLA authority, because there has been much more experience with the use of accelerated actions under CERCLA than there has been with the corrective action portion of RCRA, whose guidelines are still evolving. Although the PEIS is being developed to evaluate activities for all of DOE-EM's programmatic responsibilities (i.e., ER and EM), this report considers the impact of the PEIS only on DOE-ER's activities. 


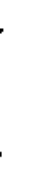




\subsection{SUMMARY OF REGULATIONS AND GUIDANCE FOR ACCELERATED ACTIONS}

Utilizing early action to reduce immediate risk to human health and the environment has been a long-standing goal of the CERCLA or "Superfund" program. The present NCP (55 FR 8666) encourages the use of early action at appropriate sites to abate the immediate threat to human health and the environment. EPA further promotes the responsiveness and efficiency of the Superfund program by encouraging action prior to or concurrent with conducting an RI/FS and as soon as there is sufficient information to support remedy selection. The NCP provides the regulatory framework for the use of removal actions and interim actions designed to accelerate the cleanup process at both National Priorities Listed (NPL) and non-NPL sites.

The purpose of this section is to summarize the regulations and guidance that apply to conducting accelerated cleanup actions. This document focuses on application of accelerated actions at NPL sites. These actions are equally applicable at non-NPL sites. This section also provides an overview of DOE$E R^{\prime} S$ PEIS and its possible impact on remedial actions.

The intent is not to give an exhaustive review of the guidance and regulations relating to accelerated actions, but rather a brief summary and outline of the appropriate guidance and regulations that are used to determine the purpose, applicability, and role of accelerated actions at NPL sites. For more detailed guidance on applicable regulations, the OSWER directives referenced throughout this section should be obtained. For guidance on implementing accelerated actions under $D O E^{\prime}$ s environmental restoration program, the DOE office of Environmental Guidance (EH-23) should be contacted.

\subsection{DEFINITION OF TERMS}

During the evolution of Superfund, the terms describing early removal or remedial actions have been used in various and inconsistent ways. For example, during the site interviews terms used to describe accelerated actions were used interchangeably by DOE and EPA staff. These terms commoniy include removals, removiais, removal actions, interim actions, interim and expedited 
remedial actions, and interim and expedited response actions. Confusion is added to the terminology because often the terms are used inconsistently.

Understanding the terminology that is used to describe accelerated cleanup actions is important for DOE. Consistent use of accelerated action terminology is imperative for effective communication internally and with regulatory agencies. This report attempts to clarify the use of accelerated action terminology by providing the original definitions used in EPA guidance. However, the rationale for much of EPA's accelerated-action terminology is based on the allocation of funds within the Superfund program. Because DOE's environmental restoration program is not funded by Superfund, many of the distinctions between terms are not directiy applicable. The probable distinctions between EPA's terminology and its relevance to DOE's activities are therefore highlighted in the terminology discussion.

The NCP (55 FR 8666) describes and encourages the use of interim actions. EPA has developed guidance for using accelerated actions (EPA 1984; EPA 1988a), for conducting expedited response actions (EPA 1987), and to expedite remedial design and action (EPA 1990a). OOE is in the process of developing guidance for conducting accelerated actions. To ensure consistent interpretation in this report, the terms used to describe accelerated actions are defined below. Because DOE guidance on accelerated actions has not been developed to date, the definitions have been kept as consistent as possible with the terminology found in the EPA OSWER directives.

\subsubsection{Accelerated Response Actions}

An action taken at an NPL site with the intention of acting quickly to reduce acute risk to human health and the environment is an accelerated response action. These actions include removal actions performed at National Priorities List (NPL) sites, interim actions and interim remedial actions using operable units, and techniques that can be implemented to expedite the remedial planning and design phases (see Figure 2.1).

- Interim action: any action taken at an NPL site under either removal or remedial authority prior to implementing the final action described in a record of decision (ROD) or prior to the ROD's becoming final. Interim actions must be consistent with and must not 
preclude implementation of the final remedy. Interim actions include both removal actions and interim remedial actions.

- Interim remedial action (IRA): IRAs are non-final remedial actions performed at NPL sites; they make use of the early-action operable unit to pursue a ROD based on existing data or a focused, limited data-gathering effort.

- Removal action: removal actions performed at an NPL site by an onscene coordinator (OSC) under removal authority. All removal actions (including the following) conducted under EPA authority are subject to statutory limitations of being less than $\$ 2$ million in cost and 12 months in onsite activities. Wajvers are available for exceeding these Timits.

- Expedited response action (ERA): removal actions performed by remedial project managers (RPMs) using removal funds at sites on the NPL. ERAs can be used in the pre- or post-ROD phases of remedial action.

- "Removials": remedial action conducted using removal contracting methods. These actions are implemented using a ROD and remedia] funding. EPA has announced that the term "removial" should no longer be used to describe this process. This report will therefore describe the process rather than use the term "removial".

"Removials" and ERAs are examples of distinctions of interim actions that were developed to address funding issues within the Superfund program. These

\section{CERCLA}

\section{Accelerated Response Actions}

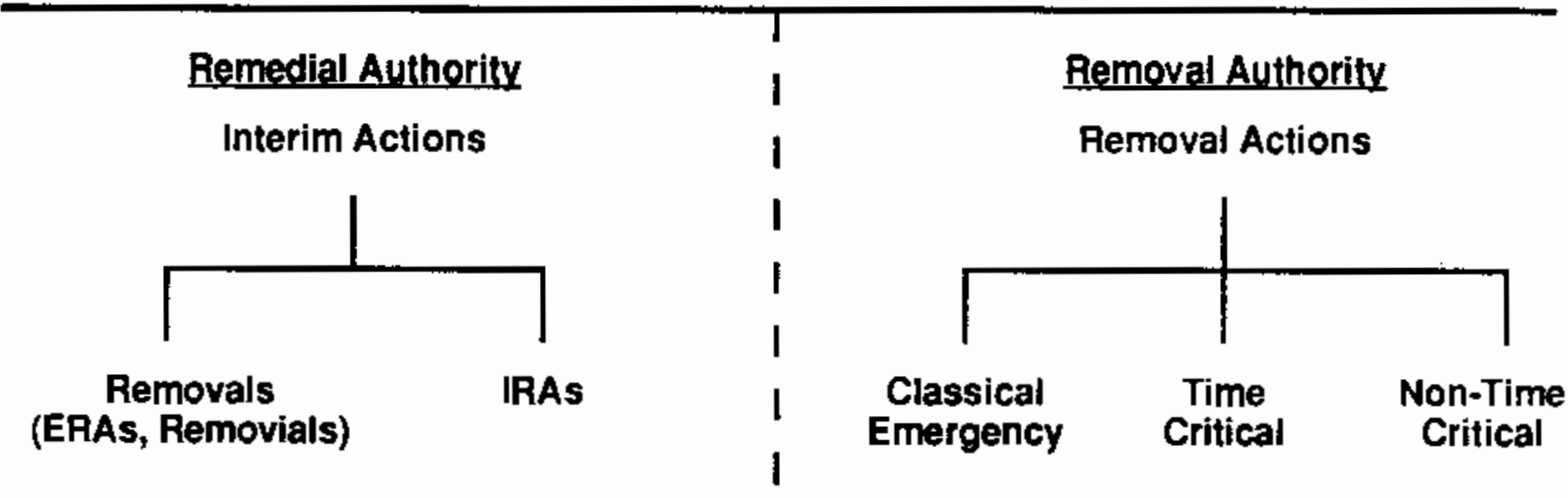

FIGURE 2.1. Accelerated Response Actions Under CERCLA 
issues are not directly relevant to DOE. The issue in accelerated actions for DOE will probably be distinguishing between removal authority (i.e., removal actions) and remedial authority (i.e., IRAs). This distinction will be important because, although DOE has been granted removal and remedial authority, the compliance requirements are substantially different for each.

It is important to understand the terminology in EPA's policy and guidance to facilitate communication with regulatory agencies. Further, after DOE guidance on accelerated actions has been developed, it will be important to understand how it differs from EPA guidance. Therefore, the appropriate use and application of these terms according to EPA guidance and regulations will be discussed in more detail in the following paragraphs. The remainder of Section 2 describes the two main groupings of accelerated actions, which are removal actions (including ERAs) and IRAs, and then addresses the DOE-ER PEIS.

\subsection{REMOVAL ACTIONS}

A7 though DOE has the authority to act as the OSC at its sites, it must comply with the substantive requirements of NEPA, CERCLA and the NCP. As per the notice Compliance With the National Environmental Policy Act (NEPA): Amendments to DOE Guidelines (55 FR 37174), DOE has agreed to voluntarily adopt the statutory 1 imitations EPA placed on Superfund-financed removals, at least with respect to NEPA compliance. These limits specify that the actions shall cost no more than $\$ 2$ million and take no longer than 12 months to complete once onsite activities are initiated. At the present, waivers to exceed these limitations are available from DOE headquarters ( $H Q$ ) on a requestspecific basis. In this notice, DOE also stated that many actions corresponding to removal actions may be categorically excluded from NEPA requirements as long as the $\$ 2$ million/12 month statutory 1 imit is complied with or a waiver is obtained from DOE-HQ.

Subpart $K$ of CERCLA, which specifically addresses federal facilities, is due to be promulgated soon by EPA. Language in the draft report officially imposes the statutory 1 imits on removal actions at federal facilities. The statutory limits on removal actions will still apply for determination of 
catagorical exclusions from NEPA requirements. It appears waivers to the statutory 1 imits will still be approved by DOE-HQ.

Removal actions may be applicable for use at DOE sites under either remedial or removal authority, depending on the circumstances. In general, removal authority can be used to accelerate response without fulfilling remedial requirements (RI/FS, ROD, etc.). Similarly, remedial authority may be appropriate if the action complies with both removal and remedial requirements. The dividing 7 ine between removal and remedial authority is not clearly defined and is determined on a site-specific basis. OSWER Directive 9200.2-02 (EPA 1989) does note that if the action is going to require extensive, long-term response, such as restoration of a contaminated aquifer, the response should be performed under remedial authority. Specific removal and remedial requirements are discussed in the following material.

\subsubsection{Applicability and Use}

Removals at NPL sites are appropriate anytime that the lead agency at a site determines that a threat to public health or welfare or to the environment exists, and action can be taken to abate, mitigate, or eliminate that threat (55 FR 8666). If possible, removal actions should be consistent with the long-term remedial action. Examples of removal actions can include the use of institutional controls (e.g., fencing, warning signs); creating drainage controls to prevent surface-water runoff(on) from(to) contaminated areas; excavating or consolidating contaminated soils; physically removing drums or barrels; capping or containing contaminated soils and sludges; stabilizing berm, dikes or impoundments; and providing alternative water supplies.

The NCP lists factors to be considered in determining the applicability of a removal action at a site (55 FR 8666). These factors include:

- Actual or potential exposure to nearby human populations, animals, or the food chain from hazardous substances, pollutants, or contaminants

- Actual or potential contamination of drinking water supplies or sensitive ecosystems 
- Hazardous substances, pollutants, or contaminants in drums, barrels, tanks, or other bulk storage containers that may pose a threat of release

- High levels of hazardous substances, pollutants, or contaminants in soils, largely at or near the surface, that may migrate

- Weather conditions that may cause hazardous substances, pollutants, or contaminants to migrate or be released

- Threat of fire or explosion

- The avajlability of other appropriate federal or state response mechanisms to respond to the release

- Other situations or factors that may pose threats to public health, welfare, or the environment.

These factors are used for consideration purposes only. Removal actions may also be appropriate for situations other than those listed here (EPA 1989).

\subsubsection{Types of Removal Actions}

DOE's Office of Environmental Guidance is currently developing DOE policy for conducting removals. It may be that DOE's policy and terminology will differ from that used by EPA, but for now it is important to be familiar with and have an understanding of EPA's policy and terminology concerning removal actions in order to communicate effectively with EPA.

There are three basic removal actions available for use at NPL sites in the Superfund program: classic emergencies, time-critical removals, and nontime-critical removals. These may be distinguished from one other by the time avajlable before response must begin.

\section{Classic Emergencies and Time-Critical Removals}

Classic emergencies and time-critical removals are those in which the response must be initiated in less than six months. These actions are generally conducted for EPA by an OSC under removal authority and are typically done in the pre-ROD stage. The major difference in implementing a classic emergency versus a time-critical removal is in the level of detail required in 
the administrative record and in the level of public participation. DOE will probably have an OSC-equivalent to conduct removal actions.

A classic emergency exists when a risk of death, injury, or catastrophic environmental damage from hazardous substance releases is an actuality or is potential in a matter of hours or days. A time-critical removal action is appropriate when the time span for actual or potential risk to human health and the environment is on the order of weeks or months.

Action Memoranda are used as the primary decision documents in both classic emergencies and time-critical removal actions. The Action Memorandum is used for substantiating the need for a removal response, identifying the proposed action, and explaining the rationale for a removal. If the statutory limits on time and money are to be exceeded, the Action Memorandum must contain the exemption request. A detailed description of the information that must be included in an Action Memorandum can be found in the Superfund Removal Procedures Manual (EPA 1988b). The information should include the purpose; site conditions and background; threats to public health, welfare, or the environment; endangerment determination; exemption from statutory limits; proposed actions and estimated costs; expected changes in the situation should action be delayed or not taken; important policy issues; and recommendations. The Action Memorandum also serves as a critical component of the administrative record.

Depending on whether the removal action is a classic emergency or a timecritical one, community relations programs must be conducted and health and safety plans prepared to some extent to initiate action. The requirements are minimal for a classic emergency: notification of those people who will be immediately affected and state and local officials, and preparation of a Health and Safety Plan in compliance with Occupational Safety and Health (OSHA) requirements.

For a time-critical removal, a detailed community relations program with notice of availability of the administrative record and a public comment period with written responses is required. If the removal action is expected to take longer than 120 days, interviews must be conducted, a formal community 
relations plan prepared, and a local information repository established. Health and safety requirements are equivalent to those required for classic emergencies.

Actions taken under removal authority by EPA use emergency response contractors (ERCs). The advantage of this contracting mechanism is that it is in place so that work can be performed on short notice as would be required in an emergency situation. As with all removal actions, statutory limits of $\$ 2 \mathrm{mil}$ lion and 1 year apply unless a waiver is granted.

\section{Non-Time-Critical Removal Actions}

Non-time-critical removal actions are those with more than six months allowable planning time. The procedure to implement non-time-critical removals is therefore more rigorous. If the action is performed under removal authority, it can be performed prior to the development of a ROD (EPA 1989). When performed under remedial authority, the action can be an expedited response action (ERA) (pre-ROD) or it can have a ROD developed to address the removal action. Either way, the planning process closely resembles the remedial RI/FS, ROD process.

The pre-ROD planning process is based on an engineering evaluation/cost analys is $(E E / C A)$. EPA guidance notes that an RI/FS may be prepared as an al ternative to the EE/CA (EPA 1987). The detaj1 of the EE/CA development should be commensurate with the scope of the removal action being taken. According to EPA guidance (EPA 1987), elements of the EE/CA should include: site characterization data (with sampling plan if necessary); identification of removal action objectives in terms of statutory 1 imits, cost, and schedule; applicable or relevant and appropriate requirements (ARARs); identification of removal alternatives; analysis of the removal alternatives with comparative analysis; and the proposed removal action.

Similar to classic emergency and time-critical removals, Action Memoranda serve as the decision documents and as the critical components in the administrative record. The elements of Action Memoranda are consistent with the requirements (discussed in Section 3.2.1) of the decision document for classic emergency and time-critical removal actions. Three requirements that must be 
met prior to initiating action are 1) conducting a community relations program, 2) preparing health and safety plans to comply with OSHA requirements, and 3 ) reporting to the lead agency.

\subsection{INTERIM REMEDIAL ACTIONS}

The purpose of the remedial action process is to implement measures that eliminate, reduce, or control long-term risks to human health and the environment. EPA has stated that it encourages implementing interim action operable units to prevent exposure or control risks posed by a site. However, the interim action operable units must be consistent with and not preclude implementation of the expected final remedy. Interim actions include both removal actions and IRAs. This section will focus on IRAs.

In essence, IRAs are intended to be the vehicles used to achieve accelerated remedial action on a portion of an NPL site by focusing efforts on a specific subsection of the site or operable unit. IRAs can be used to eliminate, reduce, or control the hazards posed by a site or to expedite the total site cleanup. Technically, IRAs are considered to be "remedial action" even if the interim measures include source control maintenance activities.

According to NCP guidelines, the first step in IRAs' implementation is to define an operable unit for which an interim action is appropriate. The process of implementing an IRA is similar to the non-interim action remedial process (i.e., RI/FS, ROD, RD, RA). An accelerated action is obtained by focusing the documentation on the interim action operable unit rather than on the entire site.

If a remedial action is under way at the entire site, data sufficient to support the IRA decision may be extracted from the ongoing site-wide RI/FS, and an appropriate set of alternative general response actions can be evaluated. The analysis of alternatives for the FS is much more focused (i.e., a focused feasibility study) and in some cases might be limited to just one alternative. A completed baseline risk assessment is generally not necessary to justify an IRA. Qualitative risk information should be organized to demonstrate that the action is necessary to stabilize the site, prevent further degradation, or achieve significant risk reduction quickly. Supporting data, 
including risk information and the alternatives analysis, can be documented in a focused RI/FS. However, in cases where the relevant data can be summarized briefly and the alternatives are few and straightforward, it may be adequate and more appropriate to document this supporting information in the proposed plan that is issued for public comment. As a remedial action, a ROD is required which should contain a summary of the above information. While the documentation of IRA decisions may be more streamlined than for final actions, all appropriate public, state, and natural resource trustee participation procedures must be followed.

The remedial design (RD) and remedial action (RA) phases may be pursued using accelerated design and construction procedures also. These can include expediting remedial construction (OSWER Directive \#9355.5-02), phasing RD and RA, fast-tracking construction, use of preplaced and prequalified contracts such as the U.S. Army Corps of Engineers (COE) Preplaced Remedial Action and Rapid Response (RR) contracts. OSWER Directive 9355.5-02 Guidance on Expediting Remedial Design and Remedial Action provides greater detail on these options (EPA 1990a).

\subsection{DOE-EM'S PROGRAMMATIC ENVIRONMENTAL IMPACT STATEMENT}

Accelerated actions may be of use to $\mathrm{DOE}^{\prime} \mathrm{s}$ environmental restoration program as a way of initiating early actions to reduce the possibie risks posed by their waste sites. However, DOE could use the interim action subset of accelerated actions to comply with NEPA regulations if it is not possible to determine final actions while the PEIS is pending. Because of this possibility, the elements of the DOE-EM's PEIS that impact DOE-ER are summarized here.

\subsubsection{DOE'S NEPA POTicy}

Although DOE has adopted a complex-wide policy of applying NEPA to its environmenta] restoration activities, the full effect of integrating NEPA requirements in the CERCLA remedial process is largely unknown. One impact of DOE compliance with NEPA is the environmental restoration and waste management PEIS DOE is planning to develop. The stated purpose of the PEIS is to "assess the potential environmental consequences of alternatives for implementing an 
integrated environmental restoration and waste management program" (DOE 1990). The general requirement of NEPA in DOE's environmental restoration effort is that DOE ensure that a reasonable number of alternative proposals are analyzed.

\subsubsection{PEIS Outline}

DOE's Notice of Intent to prepare the PEIS provides insight into what it foresees as its role in the environmental restoration effort. The PEIS will not impact the established practices in conducting ongoing restoration activities; it will be used to address national issues in DOE's environmental restoration program. These issues include 1) the extent to which existing technologies should be relied upon to conduct environmental restoration, 2) how wastes will be managed until appropriate technology and disposal needs are met, 3) whether facilities should invariably be restored for unrestricted use, and 4) the environmental basis for deciding on restoration priorities. The PEIS is planned to be used to examine site-specific issues only to the extent required for making complex-wide decisions for the integrated environmental restoration and waste management program (DOE-EM). Site-specific NEPA documentation will be used to address issues of local concern.

The possible conflict between the PEIS and DOE's environmental restoration schedule (agreed upon in federal facility agreements) is rooted in the NEPA requirement that the EIS process of considering alternatives cannot be precluded. Final cleanup actions may be interpreted as precluding the process until the PEIS is finalized. DOE has stated that the decision to proceed with site-specific restoration actions before completion of the PEIS will be made on a case-by-case basis. As a result, interim actions may be the necessary vehicle for conducting DOE's diverse and discrete restoration activities during the development of the PEIS. 


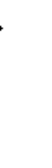




\subsection{ACCELERATED ACTION CASE HISTORIES AND ASSOCIATED ISSUES}

As discussed in Section 2, regulatory frameworks exist for conducting accelerated actions at NPL sites. Further, implementation of accelerated actions is encouraged in many parts of the NCP and in other EPA guidance documents. However, actual implementation of any accelerated action at a site involves many complicating issues not revealed in reading guidance documents. Application of accelerated actions at DOE facilities will also involve issues not directly addressed by regulations and guidance. These issues result from many things, including various interpretations of regulations by EPA regions and states, differences between EPA and DOE guidance, various public demands and pressures, and the added requirements of DOE interpretations of NEPA in the environmental restoration effort.

To better explain the incentives, problems, and benefits of implementing accelerated actions, this section presents case histories and discusses issues related to accelerated actions performed at the sites. The case histories were selected on the basis of discussions with former and current EPA and DOE staff. Telephone interviews, site visits, and reviews of compliance documentation were used to gain insights into the selected case histories. The selected sites are in EPA Regions III (Philadelphia, PA), IV (Atlanta, GA), and VII (Kansas City, KA). In Region III, RPMs were interviewed to discuss removal actions and interim remedial actions. An OSC and representatives of the Regional Counsel office discussed the Region IV view of removal actions, and in Region VII contractors at a DOE facility provided insights into suc. cessful implementation of removal and interim remedial actions at a federal facility.

\section{I SELECTED ACCELERATED ACTIONS IN EPA REGION III}

Region III is currently conducting both removal actions and interim remedial actions at NPL sites. Removal actions are being performed under remedial authority at Drake and Fike Chemical NPL sites. An interim remedial action has been proposed at the Greenwood Chemical NPL site to contain groundwater contaminants. 
Sources for this section include interviews with Region III RPMs in charge of the NPL sites (interviews with Darius Ostrauskas and Roy Schrock, November 31, 1990), and related compliance documents (EPA 1986; EPA 1988c; and EPA 1990b).

\subsubsection{Removal Actions}

The Fike Chemical and Drake NPL sites are similar in that they are both former industrial sites with abandoned structures and buildings; both have contaminated soils, sludges, and liquids in ponds and lagoons. A7though the objectives of achieving building demolition and debris removal were similar at each of these sites, the incentives for performing the removal actions under remedial authority were different.

\section{Drake Removal Action}

The Drake site is an eight-acre inactive site containing six major buildings, including production facilities and a wastewater treatment plant. Inside and surrounding the process buildings are approximately 60 process tanks and reactors. Ten large storage tanks used for bulk storage of acids, bases, and fuel oils are also located on the property. Also found on the site are two lined wastewater treatment lagoons and three unlined lagoons. Chemical sludge and contaminated soil covers or underlies much of the open area on the site; drums and bulk wastes may also be buried here. Construction debris is strewn about the site. Buildings, tanks, and debris were found to be contaminated with a variety of organic compounds including 2,3,6-trichlorlphenyl acetic acid (Fenac), beta-naphthylamine, chlorobenzene, toluene, and bis(2-ethylhex1)phthalate.

An RI/FS was performed in the traditional manner with no attempt to accelerate the process. An operable unit RI/FS was developed to address the tanks, buildings, and structures on the site. The remedial alternative selected for this operable unit included demolition of the tanks, buildings, and structures; decontamination of saivageable material (metals); and offsite disposal. The ROD identified the selected remedial alternative as a removal action. The RD followed the traditional process with COE developing the design. 
The RA portion of the project, however, utilized some innovative contracting techniques in an attempt to accelerate the process. Removal contractors, using remedial funds, implemented the RA; regional personnel felt very comfortable using the removal contractors in this situation. They believed that since removal contractors perform this type of work under removal authority routinely, they are better suited to do removal work than typical remedial contractors. The RPM indicated that the ability to use a removal contractor clearly saved time and money compared to what it would have cost to perform this work under a remedial contract. Regional staff believe that this approach should be taken when building demolition and debris removal actions are anticipated.

\section{Fike Chemical Removal Action}

The Fike Chemical site consists of abandoned industrial structures, contaminated soils, ponds, and sludges. During the RI, Region III staff determined that the site presented an imminent threat to human health and the environment. In order to determine the extent of soil contamination, it was necessary to remove the buildings and other structures on the site. Initially, removal authorities were used at this site and an action memorandum was issued for the demolition and removal of all the structures. A removal contract was identified as the method of proceeding with a very limited design. The limited design was intended to allow faster demolition of the buildings. The RD for building demolition was considered fairly straightforward by Region III staff.

An Emergency Response Contractor (ERC) was given the work assignment to perform the building demolition and removal. A concern arose that since ERCs contracts are preplaced, the public might infer that the competitive bid process was not properly followed. The RPM view was, however, that since the ERC subcontracts the majority of this work in a competitive manner, the spirit of the competitive bid process was complied with. The Regional office is also attempting to get the $\mathrm{COE}$ to act as independent oversight of the work being performed at the site. The Fike Chemical site RPM thought that only COE construction managers and EPA OnSite Coordinators (OSCS) have the appropriate training to manage these time and materials contracts. 
At this site, over $\$ 5$ million had been spent under the removal authorities when it was decided that remedial money would have to be used to continue to fund the project. To allow for this, a ROD was signed and work was continued by the ERC using remedial funds. The language in the ROD was said to be very similar to that in the Action Memorandum. Some concern by EPA-HQ has since arisen that no RI/FS was performed at this site, and inappropriate shortcuts may have been taken. Regional staff believe that this action (use of remedial funds) was necessary to protect human health and the environment.

\subsubsection{Interim Remedial Actions at the Greenwood Chemical Site}

Greenwood Chemical Company operated a low-volume chemical manufacturing facility at the site for 40 years, producing chemicals for use in industrial, agricultural, pharmaceutical and photographic processes. Potential contaminants produced or used at the site include napthelene acetic acid, 1-napthaldehyde, naphthoic acid, toluene, naphthalene derivatives, sodium cyanide, and inorganic arsenic salts. The Greenwood Chemical site covers approximately five acres. Land surrounding the site is used for residential and agricultural purposes.

Physical features of the site include processing buildings, an office building, storage sheds, seven former treatment lagoons, and a former buried drum area. Manufacturing activities ceased in Apri1 1985, following an explosion/fire that destroyed a process building. The site was placed on the NPL in JuTy 1987.

A focused feasibility study (FFS) for groundwater at the Greenwood Chemical site was completed by EPA in September 1990. The FFS was conducted in response to concern that contaminants could be migrating toward residential wells. The complex hydrogeology of the site prevented sufficient site characterization to allow detailed design of a pump and treat system.

An IRA has been proposed to pump and treat groundwater to reduce the toxicity, mobility, and volume of the contaminants and to limit contaminant migration. In addition to minimizing groundwater contamination, data collected during the IRA will be used to determine the effectiveness of the treatment system and to identify necessary modifications to the pumping 
system. A detailed plan for developing final remedial goals will be completed during the interim remedial design phase. It is estimated that a final remedial action will be selected through a site ROD within five years.

\section{Current Status}

The proposed plan resulting from the IRA is currently in the public comment stage before becoming final. The proposed plan summarizes IRA alternatives and cost analyses based on the nine criteria listed in the NCP.

In August 1990, EPA completed a full RI report for the Greenwood Chemical site. Data collected during the RI indicated that groundwater under the site is contaminated with a wide variety of substances associated with the chemicals used or produced by the Greenwood Chemical Company facility. Federal drinking water standards are exceeded by benzene, trichloroethene and tetrachloroethene in groundwater underlying the site. The average carcinogenic risk associated with drinking the groundwater underlying the site is estimated at $2 \times 10^{-4}$. The potential toxicity of the groundwater ranges up to a Hazard Index of 6 , with a Hazard Index of over 1 considered unacceptable for human consumption. Although no residential wells have been adversely impacted to date, groundwater is the only source of drinking water for residents within a three-mile radius of the site.

\subsection{REGION IV PERSPECTIVE ON REMOVAL ACTIONS}

Region IV sites were some of the first tests using removal actions to accelerate remedial action at NPL sites under removal authority. The primary sources used for this section were interviews with EPA Region IV staff, including 0SC Rita Ford and Associate Regional Counsels Anne Asbell and Robert Green (interviews conducted November 30, 1990), and OSWER Directive 9355.0-25 (EPA 1988a).

\subsubsection{Background}

The actions undertaken at EPA Region IV were innovative enough that EPA issued a guidance document (EPA 1988a) to summarize the actions. Region IV initially used this approach beginning in 1988 at seven sites. Opinions of the results of these actions ranged from "successful" to "questionable." 
Since the initial application of this approach EPA Region IV has continued to perform removal actions at NPL sites while incorporating the experience they gained from the earlier implementations.

\subsubsection{Implementation Perspective}

The Region IV removal group feels that it is faster and cheaper to perform removals at sites compared to remedial actions. Region IV has used a very broad and open interpretation of imminent and substantial threat to allow both the EPA and potentially responsible parties (PRPs) to conduct removals. An Administrative Order is issued to the PRPs to allow them to perform the work.

Removals are now typically done only at Superfund-financed NPL sites after the enforcement moratorium has expired. The accelerated action (i.e., the removal) is consistent with the final remedy whenever practicable. To help ensure consistency between the removal process and the final remedy at a site the Quality Assurance/Quality Control (QA/QC) of any data collection has improved to allow its use in selection the final remedy in the future.

Removals in the Region have gone over the $\$ 2$ million limit up to $\$ 6$ mitTion. Waivers have been obtained from EPA-HQ to allow the $\$ 2$ million statutory limit on removal actions to be exceeded. Here the funds sometimes come from the remedial program but are used by removal contractors. This work involves typical removal actions: soil remediation, drum removal, building demolition, and debris removal. Groundwater extraction and treatment has not yet been attempted under the removal process.

Region IV does not perform non-time-critical removals; they feel that the $E E / C A$ and public participation requirements are so cumbersome that the remedial process should be used. One result of performing only time-critical or classic emergency removals is that ARARs generally do not have to be considered.

\section{2 .3 Results}

The EPA Inspector General has recently issued a report that appears to be very critical of the early work Region IV has done allowing remedial funds to be spent under removal authority to conduct removal actions identified in the 
ROD. Regional staff indicated that procedures have been improved to better allow for tracking and internal oversight of these removal projects. Although no qualitative measure is available, regional staff also think that the implementation of removal actions at NPL sites has resulted in effective accelerated actions.

One partial measure of success could be determined by examining the original agreement between Region IV and EPA-HQ authorizing the use of this approach. It was specified in the agreement that when the removal action had been completed the sites would meet the criteria for deletion from the NPL, and the Region would "quickly proceed with a formal deletion" (EPA 1988a). To date, none of the seven sites has been deleted from the NPL; however, some of the sites are currently being considered for deletion. Since this is the first time deletions have been considered following a removal action, EPA is proceeding cautiously.

\subsection{ACCELERATED ACTIONS AT A DOE SITE IN REGION VII}

The DOE is responsible for conducting response actions at the Weldon Spring Site under its Surplus Facilities Management Program. Since 1987, the site staff have been performing removal actions and developing interim remedial actions as a part of its remedial activities, while complying with regu1 atory requirements of both CERCLA and NEPA. The We1don Spring Site was selected for use as a case history because of its apparent success in initiating and implementing accelerated actions. Since it is a part of DOE's environmental restoration program, Weldon Spring's experience may have more direct application to OOE sites attempting accelerated actions than to EPAled sites.

Sources for this section included discussions with staff from DOE-HQ (interview with Steve Woodbury, DOE-EH-222, October 29, 1990) the DOE onsite Weldon Spring Site Remedial Action Project Manager (Steve McCracken, phone conversation November 8, 1990, and interview, January 9, 1991), and from the contractors (interview with Rick Ferguson January 9, 1991) performing the work. The major compliance document used as a source for this section was MacDonnel1 et a1. (1990). 


\subsubsection{Site Background}

The We1don Spring site became contaminated as a result of U.S. Army and DOE processing and disposal activities that took place from the 1940s through the 1960s. The site consists of two noncontiguous areas: a chemical plant area and a quarry. The chemical plant area includes surface water impoundments (containing sludges and liquids with chemical and radioactive contaminants) and a number of buildings and support structures. The remainder of the area is covered with grave1, paved surfaces, and vegetation (predominantly grasses, shrubs, and sma11 trees). The quarry is located about $6.4 \mathrm{~km}$ from the chemical plant area. About $1.6 \mathrm{~km}$ downgradient from the quarry is an alluvial well field that constitutes a major source of potable water for the local county. Various wastes were disposed of in the quarry from 1942 to 1969, including contaminated soils and sediments, rubble, metal debris, and equipment.

In 1982, the site became a part of the DOE formerly utilized sites remedial action program. Remedial efforts at Weldon Spring were originally initiated subject to NEPA requirements only. Characterization activities were initiated as a part of an EIS effort. The local public became aware that the site posed a problem about this same time.

In July 1987, the EPA 1isted the Weldon Spring quarry on its NPL. At the same time, the draft EIS was rejected by the Missouri state regulators and EPA Region VII. One reason given was that the site characterization was insufficient. As they initiated the next characterization phase, DOE staff integrated the CERCLA remedial process with the NEPA requirements that were originally followed. In March 1989, the EPA expanded the NPL 1isting to include the chemical plant area.

During this time, even though the ongoing remedial efforts had been derailed by rejecting the draft-EIS, EPA Region VII, the state of Missouri, and DOE wanted to demonstrate that progress in site remediation was occurring. The three parties agreed to pursue activities that would remove hazards and stabilize wastes while conducting the overall remedial action for the site. The overall action will be addressed in an RI/FS report that will be modified to incorporate the requirements of an EIS under NEPA. The report, termed an 
RI/FS-EIS, evaluates alternatives for remediation of the chemical plant area and disposal of the wastes generated by remediation of the entire site. Various interim actions (both removal actions and interim remedial actions) were planned and performed prior to completion of the RI/FS-EIS to mitigate actual or potential releases of radioactive or chemical contaminants into the environment. The site-wide RI/FS-EIS is in its final stages and will be submitted shortly to EPA.

\subsubsection{Removal Actions}

As a part of the RI/FS-EIS, a workplan was negotiated that would identify and separate the removal actions from the RI/FS. Twenty removal actions were identified and documented in the workplan. From 1989 to the present, eleven of the removal actions have been completed. Twenty separate removal actions were no longer identifiable and were later grouped together for practical reasons during the development of the engineering evaluation/cost analyses ( $\mathrm{EE} / \mathrm{CAs}$ ).

All removal actions undertaken at Weldon Spring were ERAs; that is, they were non-time-critical removal actions, performed under remedial authority. The basic procedure followed was to develop an EE/CA report in accordance with the requirements of CERCLA and in compliance with NEPA. As a result, the $E E / C A s$ had an environmental assessment incorporated that could support a NEPA determination for the proposed actions. As required by the regulations, the removal actions proposed in the EE/CAs did not address final disposal decisions. The EE/CAs specifically stated that these decisions would be addressed in the RI/FS-EIS that was under development.

The EE/CAs developed for Weldon Spring Site Remedial Action Project (WSSRAP) included drum removals, asbestos removals, decommissioning, construction of a dike to divert overland flow, and the design of a water treatment plant for the quarry. The strategy was to start with easy cases to build experience with regulators and educate the public about the process. The EE/CAs were developed for each action at the "appropriate" level of detail; meaning that straightforward removal actions (e.g., building demolition) required a brief analysis, while complex removal actions (e.g., removal 
of contaminated water from the quarry) required a more detailed analysis. In a $11 \mathrm{EE} / \mathrm{CAs}$, the regulatory requirements (as summarized in Section 2 of this report) were followed.

An instrumental part of the strategy to perform ERAs was that the site authorities made sure that the state, EPA Region, and DOE were in agreement before beginning the removals.

\subsubsection{Interim Remedial Actions}

The first major interim renedial action undertaken at Weldon Spring addressed the management of bulk wastes in the quarry. A focused RI/FS was prepared that included an RI to present information characterizing the quarry and the wastes in the quarry, a baseline risk evaluation to assess potential exposures in the short term under current conditions, and an FS to evaluate potential alternatives for managing the bulk wastes. The quarry wastes constitute the source of contaminants migrating into the air and underlying groundwater.

The alternative selected as a result of the focused RI/FS process, which included public review and comment, was to excavate the butk wastes from the quarry and transport them to the chemical plant area of the Weldon Spring Site. Final disposal decisions for the excavated bulk wastes were addressed in the overall RI/FS-EIS.

Similar to the ERAs conducted at Weldon Spring, environmental compliance documents for the IRA were developed in coordination with EPA Region VII and the state of Kansas. The compliance documents were issued for public comment. Public involvement is an important factor in the decision-making process for site remediation. 


\subsection{CONCLUSIONS}

The purpose of this report is to determine when accelerated remedial actions are appropriate and permitted by the regulations, how they have been and are currently being implemented, and to identify and discuss related issues. To achieve this, regulatory and guidance documents were reviewed, interviews with EPA and DOE staff were conducted, and compliance documentation from NPL sites that have been involved in accelerated actions were consulted as sources for this investigation.

Based on the investigation described in this report, accelerated actions at NPL sites:

- Can include removal actions conducted under both removal and remedial authority, and interim remedial actions based on operable units. Categories of removal actions under removal authority include classic emergency, time-critical, and non-time-critical removals. In EPA guidance, non-time-critical removal actions performed under remedial authority before the ROD has been finalized are called expedited response actions. Interim remedial actions are implemented using a version of the typical remedial process that focuses on an operable unit. IRAs are currently being used to contain and treat groundwater contamination as well as for removal actions.

- Are appropriate for sites anytime action can be taken to control risks posed by a site to public health or welfare or the environment. EPA endorses a bias for action in the NCP and encourages the use of early actions. The accelerated actions taken must be consistent with the final action at a site whenever practicable. However, accelerated actions are not a "blanket" answer to implementing early actions. There are limits and potential problems (both technical and credibility) in misusing accelerated actions; in other words, the appropriateness and applicability of using accelerated actions is a site-specific issue. For example, EPA Region IV was recently investigated by the Inspector General for not meeting its stated goal of "quick" deletion of sites from the NPL as a resuTt of using accelerated actions. The appropriateness of implementing accelerated actions at DOE sites wi11 receive different rates of acceptance depending on the EPA Region, the state conducting the regulatory oversight and the reaction of the local community.

- Can be used to effectively demonstrate progress in environmental restoration efforts. Both EPA and DOE staff acknowledged that accelerated actions were useful to show the pubTic that progress was 
being made in remediating sites. It was noted in one interview session that demolition and debris removal actions had dramatic effects on satisfying public demands to make credible progress. The Weldon Spring Remedial Action Project utilized a demolition and debris removal action as one of its ERA removal actions.

- Can be implemented at DOE sites while meeting both NEPA and CERCLA requirements. DOE has recently announced that it considers many removal actions to be categorically excluded from NEPA requirements. Remedial activities being conducted at the Weldon Spring site demonstrate that NEPA and CERCLA requirements can be successfully integrated. An important issue involved in conducting these activities is maintaining effective public relations and a constructive working relationship with regulators. Again, the regulatory interpretation of these requirements will vary depending on the state and EPA region conducting the oversight.

- May be an effective means of pursuing remediation activities in the DOE environmental restoration while the PEIS is under development. No definite interpretation of the impact of the PEIS development on ongoing environmental restoration activities has been determined. The possibility exists that only interim actions may be allowed to keep from biasing the PEIS development. The regulatory framework a)lows interim actions to be used in this manner. A matter of concern may be the impact of using interim actions on the remediation schedules to which DOE has agreed in the various Federal Facility Agreements. 


\subsection{REFERENCES}

55 FR 8666. 1990. U.S. Environmental Protection Agency, "National $0 j 1$ and Hazardous Substances Pollution Contingency Plan; Final Rule." Federal Register, March 8, 1990.

55 FR 37174. 1990. U.S. Department of Energy, "Compliance With the National Environmental Policy Act (NEPA); Amendments to DOE Guidelines." Federal Register, September 7, 1990.

MacDonne11, M. M., M. L. Maxey, I. E. Joya, and J. M. Peterson. 1990. Engineering Evaluation/Cost Analys is for the Proposed Management of Contaminated Water Impounded at the Weldon Spring Chemical Plant Area. DOE/OR/21548-106, Argonne National Laboratory, Chicago.

U.S. Department of Energy. 1990. "Notice of Intent (NOI) to Prepare a Programmatic Environmental Impact Statement (PEIS), " October 15, 1990.

U.S. Environmental Protection Agency. 1986. "Superfund Record of Decision: Drake Chemical Site (Phase II), Lockhaven, PA." EPA/R0D/R03-86, ApriT, 1986.

U.S. EnvironmentaT Protection Agency. 1987. "The Role of Expedited Response Actions Under SARA." OSWER Directive 9360.0-15, Apri1 21, 1987.

U.S. Environmental Protection Agency. 1988a. "Statement of Policy on Requirements for Using Removal Authorities for Speeding up Remedial Projects." OSWER Directive 9355.0-25, December 9, 1988.

U.S. Environmental Protection Agency. 1988b. "Superfund Removal Procedures Manual, Revision 3." OSWER Directive 9360.0-03B, February 1988.

U.S. EnvironmentaT Protection Agency, 1988c. "Superfund Record of Decision: Fike Chemical, WV." EPA/ROD/R03-88/054, September 1988.

U.S. Environmental Protection Agency, 1989. "Accelerated Response at NPL Sites Guidance (Superfund Management Review: Recommendation No. 2). " OSWER Directive 9200.2-02, December 15, 1989.

U.S. Environmenta1 Protection Agency, 1990a. "Guidance on Expediting Remedial Design and Remedial Action." OSWER Directive 9355.5-02, June 4, 1990 .

U.S. Environmental Protection Agency-Region III. 1990b. "Proposed Plan Greenwood Chemical Site, Newtown, Virginia." October 1990. 


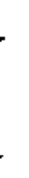




\section{DISTRIBUTION}

No. of

Copies

\section{OFFSITE}

12 DOE/Office of Scientific and Technical Information

R. Sena

U.S. Department of Energy

Environmental Restoration Project office

P.0. Box 5400

Albuquerque, NM 87115

J. Haugen

U.S. Department of Energy

Waste Management Project

Chicago Operations office

9800 South Cass Avenue

Chicago, IL 60439

J. Lyle

U.S. Department of Energy

Environmental Restoration Division

Idaho Operations office

785 DOE Place

Idaho Falls, ID 83402

J. N. Fiore

U.S. Department of Energy

Environmenta? Restoration and Waste Management Division

Nevada Operations Office

P.0. Box 98518

Las Vegas, NV 89193-8518

R. Sieeman

U.S. Department of Energy

Environmental Restoration Division

Oak Ridge Operations Office

P.0. Box 2001

Oak Ridge, TN 37831
No. of

Copies

R. Schassburger

U.S. Department of Energy

Environmenta] Restoration

Division

Rocky Flats Office

P.0. Box 928

Golden, CO 80402-0928

J. Cullen

U.S. Department of Energy

Environmental Restoration Program

Livermore Site office

P.0. Box 808/L-57

Livermore, CA 94550

L. Goidell

U.S. Department of Energy

Environmenta7 Restoration Division

Savannah River Operations office

P.0. Box A

Aiken, SC 29802

$6 \quad$ U.S. Department of Energy

19901 Germantown Rd. Germantown, MD 20545

ATTN: R. Fleming, EM-431

C. Magnuson, EM-431

D. Smith, EM-431

L. Taylor, EM-433

G. Turi, EH-433

W. Wi senbaker, EM-43

$4 \quad$ U.S. Department of Energy

ATbuquerque Operations Office P.0. Box 5400

Albuquerque, NM 87115

ATTN: J. Bickel
A. Chernoff
D. Krenz
J. Themel is 
No. of

Copies

67 U. S. Department of Energy Forrestal Building 1000 Independence Ave. Washington, DC 20585

ATTN:

R. Ade1man, WDC

R. Berube, EH-20

C. Billips, ER-8.2

C. Bradley, NE-33

R. Bradley, S-1

S. Brocoum, RW-22

A. Cleary, EH-1

J. Coleman, EM-32

S. Cowan, EM-30

R. Dailey, EH-231

H. Delaplane, FE-421

W. Dennison, GC-11

G. Dicerbo, EH-231

J. Disbrow, EI-531

C. Ebbecke, NP-20

R. Englehart, NP-50

L. Fairobent, EH-1

J. Farley, ER-9.2

J. Fiore, EM-42

J. Fisher, $\mathrm{CP}-40$

J. Ford, DP-14

C. Frank, EM-50

S. Frank, NP-54

M. Frei, EM-34

H. Garson, NP-1

R. Gisch, NE-60

K. Goodwin, DP-161

P. Grimm, EM-2

C. Halsted, DP-13

S. Hanna, PA-3

L. Harmon, EM-53

D. Jewett, FE-222

R. Jones, EH-41

A. Joseph, ER-40

J. Knight, DP-12

R. Lightner, EM-45

J. Longton, CR-14

J. Lyt le, EM-30

S. Mann, EM-44

J. McDonald, DP-20

W. Mess, ER-20

R. Moore, EI-23.1

D. Moses, PE-70

H. Myers, CE-64
No. of

Copies

G. Parker, RW-333

F. Peters, RW-2

R. Peterson, DP-222

H. Pettengi11, EH-40

T. Pflaum, DP-3

S. Richardson, DP-10

S. Richardson, DP-16

P. Ritzcovam, NP-52

J. Roderick, EM-342

R. Scott, EM-20

R. Sharma, NE-47

D. Shelor, RW-30

G. Sherwood, NE-12

D. Silawsky, FE-441

L. Smith, EM-323

K. Sprangte, DP-52

D. Swink, FE-4

T. Traceski, EH-231

J. Turi, EM-33

R. P. Whitfield, EM-40

$F$. Wolff, DP-161

R. Wood, ER-74

J. Yates, ER-42

2 U.S. Department of Energy Chicago Operations Office 9800 South Cass Avenue Chicago, IL 60439

ATTN: J. Kennedy

B. Fritz

3 U.S. Department of Energy Idaho Operations office 785 DOE Place

Idaho Falls, ID 83402

ATTN: J. Barry

P. Hinman

W. Sato

3 U.S. Department of Energy Nevada Operations Office P.0. Box 98518

Las Vegas, NV 89193-8518

ATTN: B. Church

D. Elle

J. Fiore 
No. of

Copies

3 U.S. Department of Energy Oak Ridge Operations Office P.0. Box 2001 Oak Ridge, TN 37831

ATTN: P. Gross

H. W. Hibbitts

R. Nelson

4 U.S. Department of Energy Rocky Flats Office P.0. Box 928

Golden, CO 80402-0928

ATTN: F. Lockhart

T. Lukow

R. Nelson, Jr.

M. Van Der Puy

4 U.S. Department of Energy San Francisco Operations Office

1333 Broadway

Oakland, CA 94612

ATTN: J. Davis

J. Hartman

J. Juettan

M. Kamiya

4 U.S. Department of Energy Savannah River Operations Office

P.0. Box A

Aiken, SC 29802

ATTN: L. Goidell

T. Heenan

L. Sjostrum

S. Wright

R. Waldman

U.S. Department of Energy Alaska Power Administration P.0. Box 020050

Juneau, AK 99802-0050
No. of

Copies

2 Bartlesville Project Office

P.0. Box 1395

220 N. Virginia

Barlesville, OK 74005

ATTN: A. Crawley

$T$. Wesson

2 Bonneville Power

Administration

P.0. Box 3621

Portland, OR 97208

ATTN: A. Morrell

S. Sander

D. McCollum

Morgantown Energy Technology

Center

P.0. Box 880

3610 Collins Ferry Rd.

Morgantown, WV 26507-0880

J. Keller

Naval Petroleum Reserves in California

P.0. Box 11

Tupman, CA 93276

D. Newquist

Naval Petroleum and 0 il Shale

Reserves in $\mathrm{CO}$, UT, WY

800 Werner $C t$, Suite 342

Casper, WY $\mathbf{8 2 6 0 1}$

M. Keller

Pittsburgh Energy Technology Center

P.0. Box 10940

Pittsburgh, PA 15236-0940

E. Shollenberger

Pjttsburgh Naval Reactors Office

P.0. Box 109

W. Mifflin, PA 15122-0109 
No. of

Copies

A. Seepo

Schenectady Naval Reactors office

P.0. Box 1069

Schenectady, NY 12301

2 Southwestern Power Administration

P.0. Box 1619

Tulsa, OK 74101

ATTN: D. Hayes

J. Lloyd

Strategic Petroleum Reserve Project office

Project Managenent Office 900 Commerce Road E. New Orleans, LA 70123

W. Jamison

U.S. Department of Energy

Western Area Power

Administration

P.0. Box 3402

Golden, CO 80401

P. Ramey

U.S. Department of Energy

Amarillo Area Office

P.0. Box 30030

Amaril10, TX 79120-0030

J. Morley

U.S. Department of Energy

Dayton Area Office

P.0. Box 66

Mearnesburg, $\mathrm{OH}$ 45342-0066

E. Bean

Kansas City Area Office

P.0. Box 410202

Kansas Cjty, MO 64141-0202

J. Bellows

Los Alamos Area Office

528 35th St.

Los Alamos, NM 87544
No. of

Copies

G. Johnson

Pinellas Area Office

P.0. Box 2900

Largo, FL 34649

2 U.S. Department of Energy

Waste Isolation Pilot Plant Project office (WIPP)

P.0. Box 3090

Carlsbad, NM 88221

ATTN: A. Hunt

J. Newhinney

M. Matthews, Jr.

U.S. Department of Energy

Albuquerque Operations office Uranium Hill Tailings Remedial Actions Project Offices

P.0. Box 5400

Albuquerque, NM 87115

B. Kaiser

U.S. Department of Energy

Nevada Operations Dffice

Yucca Mountain Project Office

P.0. Box 98518

Las Vegas, NV 89193-8518

W. R. Miller

Morgantown Energy Technology Center

P.0. Box 880

3610 Collins Ferry Road

Morgantown, WV 26507-0880

Remedial Action Program Information Center

Building 200

P.0. Box 2008

Oak Ridge, TN 37831-6050

5 S. J. Gianti

CH2M Hill

P.0. Box 4400

Reston, VA 22090 
No. of

Copies

ONSITE

7 DOE Richland Operations Office

J. D. Bauer, A4-52

R. M. Carosino, A4-52

R. D, Freeberg, A5-19

R. E. Gerton, A4-02

R. G. Holt, A5-19

R. D. Izatt, A5-19

J. J. Keating, A5-54

8 Battelle Washington Office

W. E. Fallon

C. A. Geffen

R. E. Gephart

J. D. Longstreth

R. V. Moraski

R. D. Quinn

S. A. Vance

J. Shorette

2 Environmental Management

R. S. Myers, $B 1-40$

P. J. Mellinger, Bl-40
No. of

Copies

3 Westinghouse Hanford Company

M. R. Adams, $\mathrm{H} 4-55$

J. G. Fidds, H4-55

J. G. Woolard, H4-55

21 Pacific Northwest Laboratory

R. C. Adams, $\mathrm{K} 6-52$

S. Q. Bennett, K6-35

G. R. Bilyard, K6-58

J. F. Keller, Kl-5l

J. P. Kohlman, K6-55

T. L. Kuusinen, K6-58

M. B. Triplett, K6-25

T. L. Stewart, Kl-25

M. S. Peffers, K6-25

M. R. Siegel, K6-58

J. D. Smyth, K6-25 (5)

Publishing Coordination

Technical Report Files (5) 


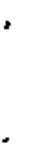

